\title{
ANALISIS PERGERAKAN SAHAM PERUSAHAAN SUB SEKTOR FARMASI MENGGUNAKAN INDIKATOR BOLLINGER BAND DI TENGAH PANDEMI COVID-19
}

\author{
Intan Elita*, K. Bagus Wardianto, M. Iqbal Harori \\ Jurusan Ilmu Administrasi Bisnis, Fakultas Ilmu Sosial dan Politik, Universitas Lampung \\ * intanelita9a@gmail.com
}

\begin{abstract}
This study aims to measure the accuracy of technical analysis using the Bollinger Band indicator in predicting stock prices in the middle of pandemic covid-19. The concept in this study is to compare daily stock price predictions according to technical indicators with the closing prices that occured on that day. Sample selection technique used in this research used a purposive sampling method and obtained 9 pharmaceutical sub-sector companies listed on the IDX from February to April 2020. The type of data used is a chart of the company's daily stock price movements obtained from finance.yahoo.com. The data analysis technique used was the paired sample t-test and used the SPSS 26 analysis tool. The results of this study indicate that the Bollinger indicator does not have a significant difference.
\end{abstract}

Keywords: technical analysis, moving average, bollinger band, closing price, investmen decision

\begin{abstract}
ABSTRAK
Penelitian ini bertujuan untuk mengukur keakuratan analisis teknikal dengan indikator Bollinger Band dalam memprediksi harga saham pada masa pandemi Covid-19. Konsep pada penelitian ini adalah membandingkan prediksi harga saham harian menurut indikator teknikal dengan harga penutupan yang terjadi pada hari tersebut. Teknik pengambilan sampel dalam penelitian ini menggunakan metode purposive sampling dan diperoleh sebanyak 9 perusahaan sub sektor farmasi yang terdaftar di BEI selama Februari hingga April 2020. Jenis data yang digunakan yaitu berupa grafik pergerakan harga saham harian perusahaan yang diperoleh dari finance.yahoo.com. Teknik analisis data yang digunakan adalah uji paired sample t-test dan menggunakan alat analisis program SPSS 26. Hasil penelitian ini menunjukkan bahwa indikator Bollinger tidak memiliki perbedaan yang signifikan.
\end{abstract}

Kata kunci: analisis teknikal, moving average, bollinger band, harga penutupan, keputusan investasi 


\section{PENDAHULUAN}

Pada akhir Desember 2019, masyarakat dikejutkan dengan munculnya virus baru yang menggemparkan dunia. Coronavirus atau Covid-19 adalah virus baru yang berasal dari Wuhan, Tiongkok yang menyebabkan jutaan manusia terinfeksi. Penyebaran virus corona yang telah meluas ke berbagai belahan dunia membawa dampak pada perekonomian Indonesia bahkan perekonomian dunia.

Sebagaimana terdapat pada gambar 1, resesi ekonomi yang sudah terjadi umumya dialami oleh negara-negara maju di dunia. Gejolak pandemi Covid-19 telah menghantam perekonomian secara global, tak terkecuali Indonesia. Badan Pusat Statistik (BPS) telah merilis angka pertumbuhan ekonomi Indonesia pada kuartal kedua 2020. Perekonomian Indonesia mengalami kontraksi sebesar $-5,32 \%$ (year on year) (Lihat gambar 2 ).

Pertumbuhan ekonomi kuartal I dan II pada tahun 2018-2019 berkisar pada angka 5\%. Sedangkan pada tahun 2020 mengalami penurunan signifikan lantaran adanya wabah pandemi. Adanya pandemi juga berpengaruh terhadap pasar modal Indonesia. Dilihat dari indeks saham sektoral, terdapat beberapa sektor yang masih tumbuh positif di tengah pandemi. Sektor industri konsumsi tidak mengalami penurunan yang signifikan yakni $11,55 \%$ karena kebutuhan konsumsi merupakan kebutuhan dasar masyarakat dalam situasi apapun (Lihat gambar 3).

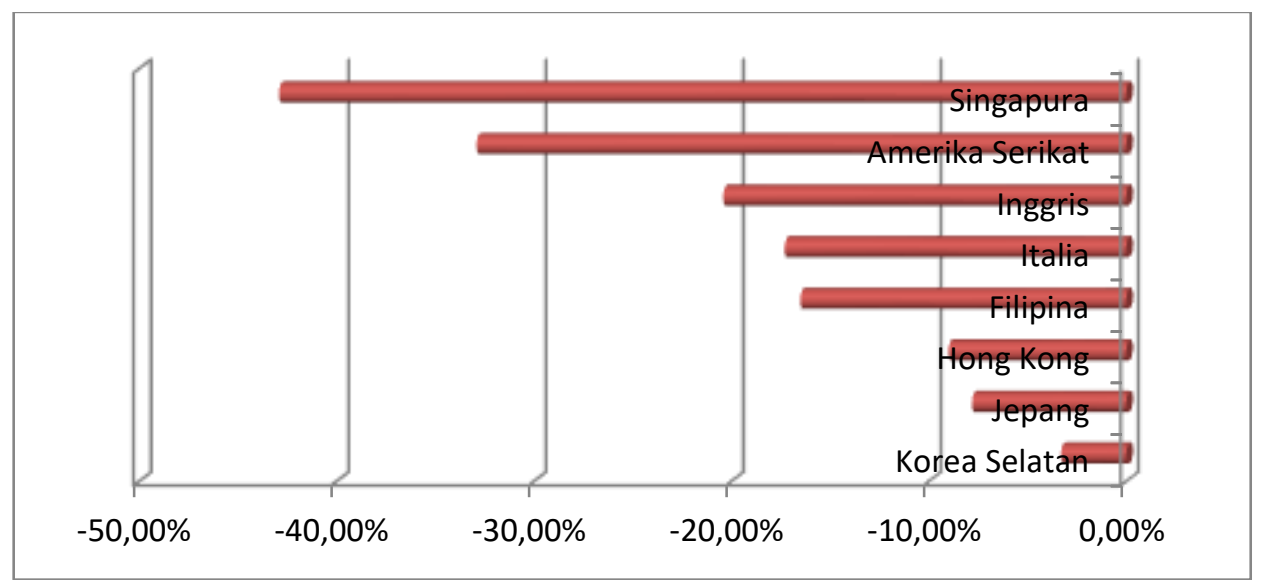

Gambar 1. Pertumbuhan Ekonomi Global Kuartal II 2020

Sumber: kompas.com (Data Diolah, 2020)

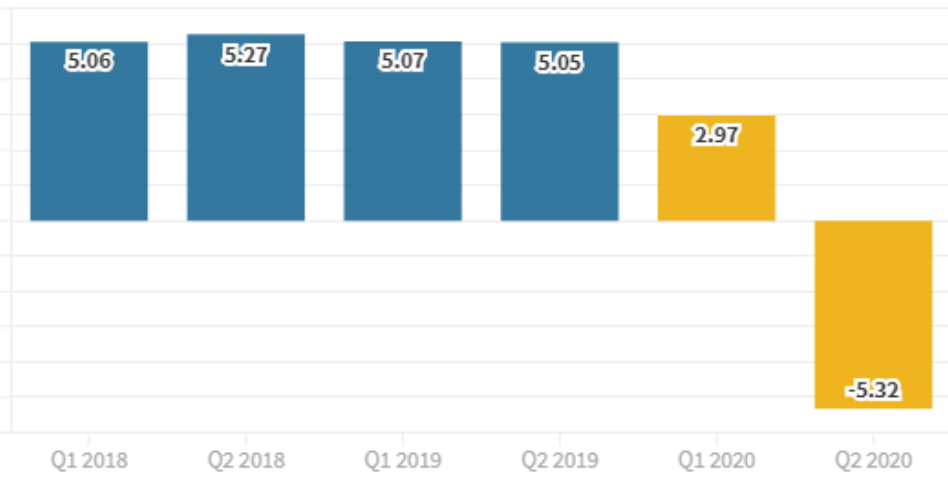

Gambar 2. Perubahan Ekonomi Triwulan I dan II Indonesia 2018-2020 Sumber: BPS 
Industri farmasi adalah salah satu industri yang termasuk dalam sektor konsumsi dan merupakan prioritas dalam perekonomian Indonesia. Selama pandemi, permintaan produk farmasi atau obat yang dapat meningkatkan daya tahan tubuh cenderung meningkat, khususnya untuk jenis obat herbal dan multivitamin. Di tengah penguatan IHSG, saham-saham emiten farmasi terus melonjak sejak awal kasus Covid-19 ditemukan di Indonesia.

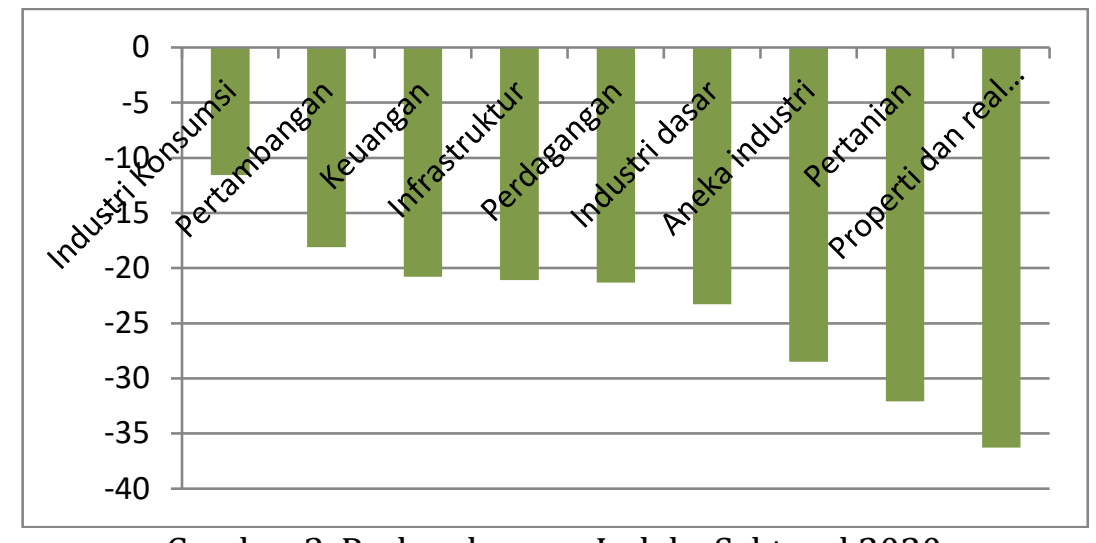

Gambar 3. Perkembangan Indeks Sektoral 2020

Sumber: Otoritas Jasa Keuangan

Tabel 1. Perbandingan Harga Saham dan Volume Perdagangan

\begin{tabular}{|c|c|c|c|c|c|}
\hline \multirow[t]{2}{*}{ No } & \multirow{2}{*}{$\begin{array}{l}\text { Kode } \\
\text { Saham }\end{array}$} & \multicolumn{2}{|c|}{1 Januari 2020} & \multicolumn{2}{|c|}{1 Juli 2020} \\
\hline & & $\begin{array}{c}\text { Harga } \\
\text { Penutupan }\end{array}$ & $\begin{array}{c}\text { Volume } \\
\text { Perdagangan }\end{array}$ & $\begin{array}{c}\text { Harga } \\
\text { Penutupan }\end{array}$ & $\begin{array}{c}\text { Volume } \\
\text { Perdagangan }\end{array}$ \\
\hline 1 & KAEF & 1000 & 191.687 .200 & 2250 & 971.361 .600 \\
\hline 2 & INAF & 840 & 265.897 .200 & 2280 & 366.346 .600 \\
\hline 3 & KLBF & 1430 & 359.837 .100 & 1565 & 2.083 .450 .100 \\
\hline 4 & PYFA & 185 & 263.800 & 890 & 114.397 .400 \\
\hline 5 & DVLA & 2190 & 193.900 & 2320 & 1.965 .400 \\
\hline 6 & SIDO & 1195 & 75.594 .500 & 1300 & 154.505 .900 \\
\hline 7 & MERK & 2450 & 255.300 & 3660 & 6.188 .100 \\
\hline 8 & PEHA & 960 & 399.600 & 1455 & 29.520 .400 \\
\hline 9 & TSPC & 1295 & 7.075 .000 & 1380 & 15.289 .600 \\
\hline 10 & SCPI & 29000 & 0 & 29000 & 0 \\
\hline
\end{tabular}

Tabel 1 menunjukkan bahwa saham-saham farmasi mengalami lonjakan harga dan volume yang sangat signifikan dalam kurun waktu enam bulan. Para analis memprediksi bahwa pertumbuhan positif yang terus berlanjut itu hanya akan bersifat sementara (liputan6.com, 2020). Hal ini lantaran kondisi perekonomian nasional bahkan global sedang tidak stabil di tengah wabah pandemi Covid-19. Untuk mengantisipasi risiko akibat perubahan harga saham yang berfluktuatif maka diperlukan sebuah analisis yang dapat dijadikan dasar pengambilan keputusan investasi.

Analisis teknikal adalah suatu metode pengevaluasian saham, komoditas, ataupun sekuritas lainnya dengan cara menganalisis statistik yang dihasilkan oleh aktivitas pasar di masa lampau guna memprediksikan pergerakan harga di masa mendatang (Ong, 2016). Data-data yang dipakai dalam analisis teknikal adalah data-data pasar yang bersifat sebagai data historis. Menurut Sunariyah (2013) disebutkan bahwa sasaran yang ingin 
dicapai pada pendekatan ini adalah ketepatan waktu dalam memprediksi pergerakan harga (price movement) jangka pendek suatu saham maupun suatu indikator pasar. Indikator teknikal secara garis besar dibagi menjadi dua kelompok, yaitu lagging indicator dan leading indicator. Lagging indicator adalah indikator yang berfungsi untuk mendeteksi trend, misalnya Bollinger Band. Indikator Bollinger Band melibatkan perhitungan volatilitas harga saham menggunakan dua garis Moving Average yaitu garis batas atas (Upper Band) dan garis batas bawah (Lower Band) (Ong, 2016).

Perhitungan rumus pada indikator Bollinger Band sebagai berikut:

Middle Bollinger Band berdasarkan $n-$ day $M A$

Upper band $=$ Middle band $+2 \times n$ period Standar Deviasi

Lower band $=$ Middle band $-2 \times n$ period Standar Deviasi

Tujuan dari penelitian ini yaitu untuk mengetahui apakah terdapat perbedaan signifikan antara prediksi harga saham Bollinger Band dengan harga realita yang terjadi. Berdasarkan tujuan tersebut, maka hipotesis dalam penelitian ini adalah sebagai berikut:

H0: Tidak terdapat perbedaan yang signifikan antara prediksi harga dari indikator Bollinger Band dengan harga realita.

Ha: Terdapat perbedaan yang signifikan antara prediksi harga dari indikator Bollinger Band dengan harga realita.

\section{METODE PENELITIAN}

Penelitian ini merupakan jenis penelitian deskriptif dengan pendekatan kuantitatif. Populasi dalam penelitian ini adalah seluruh emiten saham sub sektor farmasi yang terdaftar di BEI periode Februari hingga April 2020. Penarikan sampel dalam penelitian ini menggunakan non probability sampling dengan teknik sampling yang digunakan yaitu purposive sampling, teknik pengambilan sampel dengan didasarkan ciri- ciri khusus yang sesuai dengan tujuan penelitian sehingga diharapkan dapat menjawab permasalahan penelitian (Sugiyono 2017). Sampel dalam penelitian ini sebanyak 9 perusahaan, dengan kriteria perusahaan yang tidak delisting ataupun sedang dalam proses delisting selama periode penelitian.

\section{HASIL PENELITIAN}

Dalam penelitian ini indikator Bollinger Band digunakan untuk memperoleh informasi akan penerusan arah tren dan besaran volatilitas harga saham yang digambarkan melalui pita Bollinger. Periode perhitungan menggunakan setting standar yang direkomendasi oleh John Bollinger adalah 20 - 2. Artinya menggunakan MA-20 dengan 2 Standar Deviasi (SD). Analisis yang dilakukan dalam penelitian ini disajikan dalam bentuk grafik sebagai berikut.

Analisis Saham pada PT Indofarma Tbk 


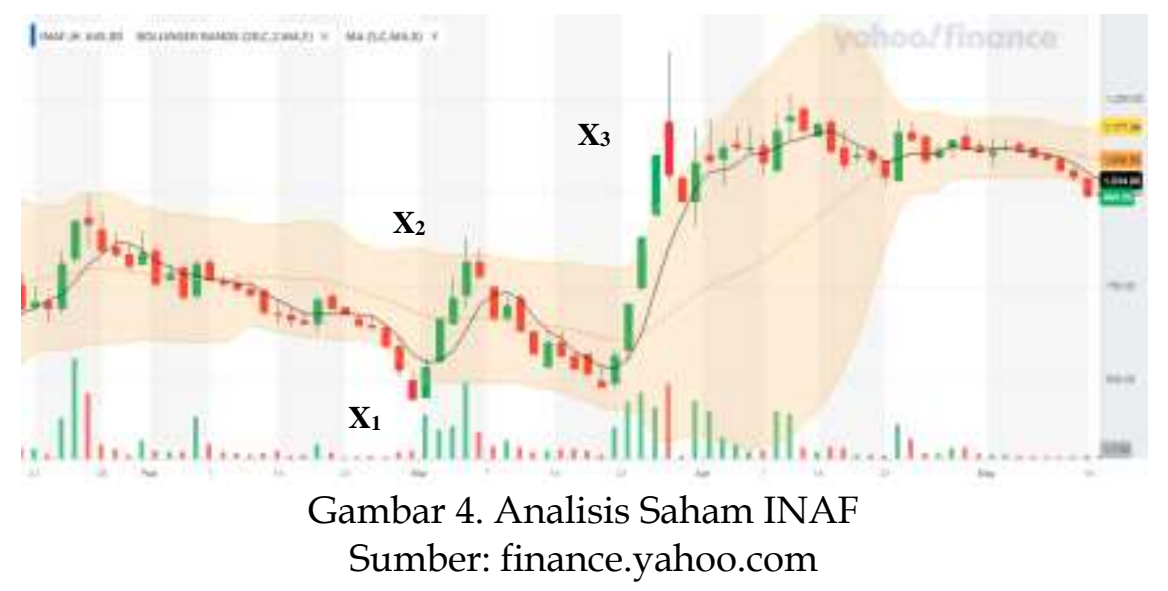

Berdasarkan gambar 4, terlihat bahwa titik X1 harga berada di bawah lower band yang menunjukkan bahwa pasar sedang dalam keadaan oversold yang memberikan sinyal beli. Harga terus bergerak dalam trend naik hingga pada titik X2 harga menembus upper band dengan harga penutupan Rp815. Hal ini menunjukkan keadaan overbought dan disarankan untuk menjual karena harga akan bergerak dalam trend turun. Pada titik X3 harga saham menembus garis upper band yang dan trader sebaiknya menjual sahamnya karena harga berada pada rentang Rp900 - Rp1100.

Analisis Saham pada PT Kalbe Farma Tbk

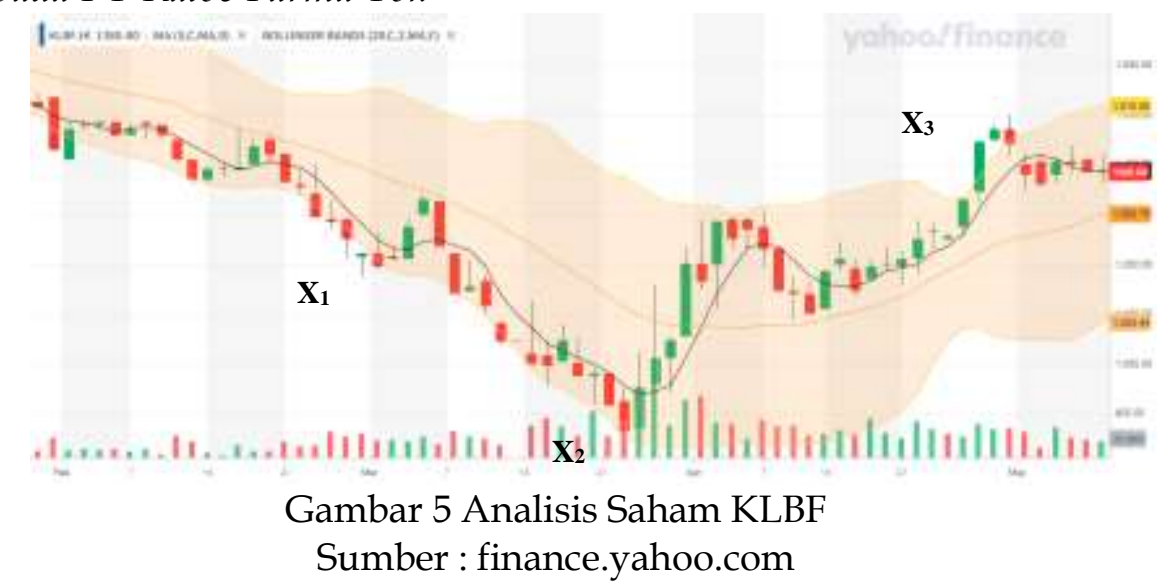

Dari gambar 5 diketahui bahwa pada bulan Februari, emiten saham KLBF cenderung downtrend. Harga menembus lower band pada titik X1 dengan harga terendah Rp1185 dan mengindikasikan sinyal beli. Di awal Maret terjadi pembalikan trend, harga cenderung bergerak dalam trend turun hingga akhir Maret. Selanjutnya harga kembali bergerak dalam trend naik pada titik X2 dan pita bollinger melebar. Kondisi ini merupakan saat yang tepat bagi trader untuk mengambil keputusan beli. Selanjutnya pada titik X3 harga menembus upper band dengan harga tertinggi yakni Rp1445. Pada kondisi seperti ini trader disarankan untuk menjual sahamnya.

\section{Analisis Saham pada PT Kimia Farma Tbk}

Pergerakan harga saham Kimia Farma di bulan Februari cenderung downtrend. Kemudian pada titik X1 harga memotong lower band dengan harga terendah Rp540. Dari indikator tersebut menunjukkan bahwa harga akan bergerak naik sehingga trader disarankan untuk mengambil keputusan beli pada kondisi ini. Selanjutnya terjadi 
peralihan trend, harga belum menyentuh upper band. Pada titik X2, harga mencapai upper band yang mengindikasikan overbought atau sinyal untuk menjual dengan harga penawaran tertinggi yaitu Rp1400. Pada akhir bulan April pita bollinger dalam keadaan menyempit, harga saham cenderung bergerak mendatar dari bulan April sampai Mei.

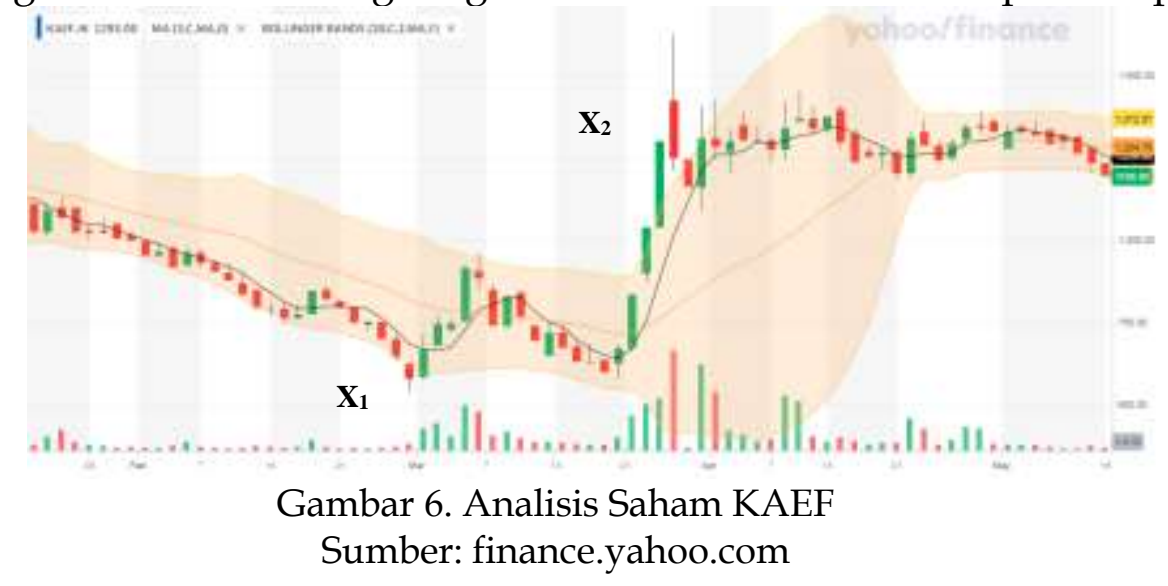

Analisis Saham PT Darya-Varia Laboratoria Tbk

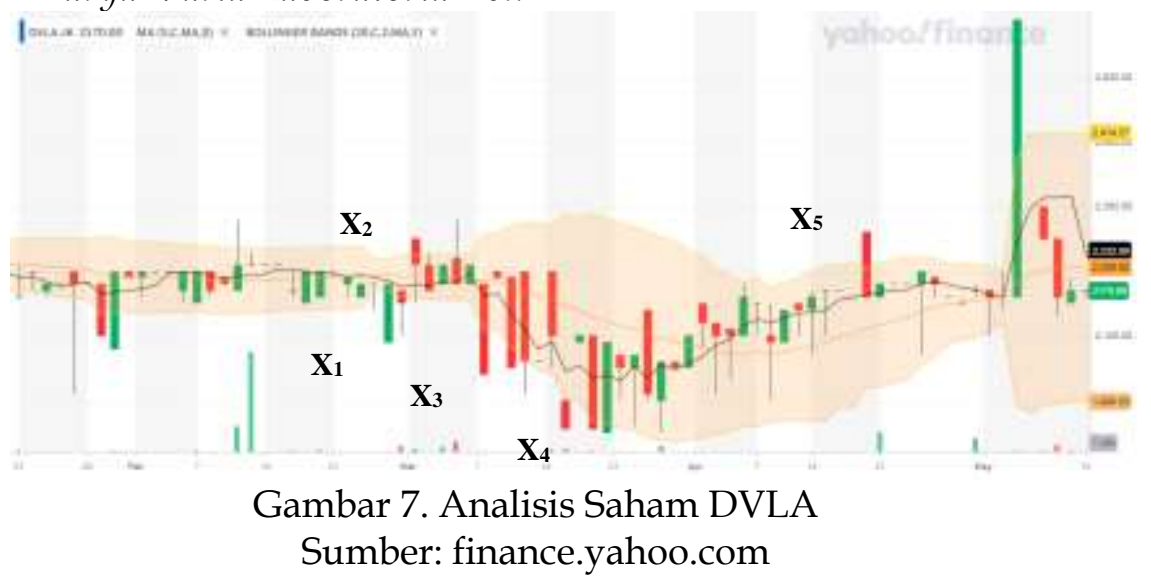

Gambar 7 menunjukkan bahwa pergerakan harga cenderung downtrend pada bulan Februari. Titik X1 dan X2 menunjukkan bahwa harga telah menembus garis bollinger namun pita bollinger dalam keadaan sempit. Pada kondisi ini trader disarankan tidak tergesa-gesa dalam mengambil keputusan. Trader bisa membeli pada titik X4 saat harga menembus lower band dengan harga terendah Rp1955 dan pita bollinger melebar. Sedangkan keputusan jual dapat diambil pada saat harga menembus upper band (X4) dengan harga tertinggi Rp. 2.260.

\section{Analisis Saham PT Merck Tbk}

Pergerakan harga saham MERK pada bulan Februari cenderung downtrend. Pada awal bulan Maret bertepatan dengan adanya pengumuman munculnya virus corona di Indonesia harga bergerak menyentuh lower band (X1) dengan harga terendah Rp1900. Hal ini mengindikasikan sinyal beli karena harga diprediksi akan bergerak naik. Selanjutnya harga menembus lower band (X2) dengan harga terendah Rp1350 serta pita bollinger melebar. Hal ini menunjukkan keadaan oversold dan harga akan mengalami uptrend. Pada kondisi ini, trader sebaiknya mengambil keputusan membeli saham. 


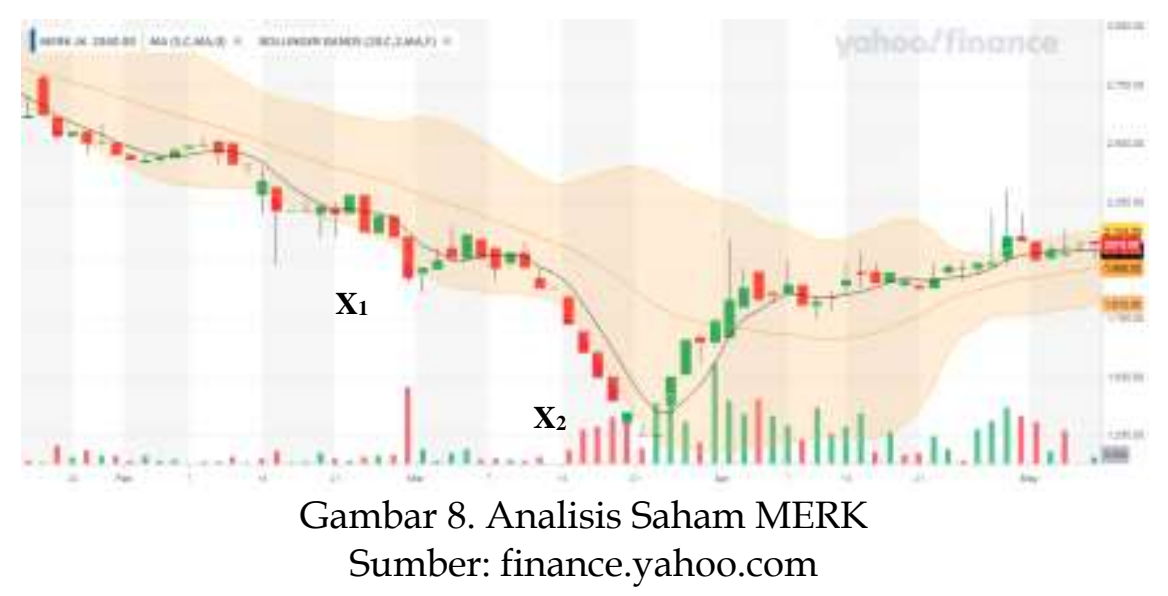

Analisis Saham PT Pyridam Farma Tbk

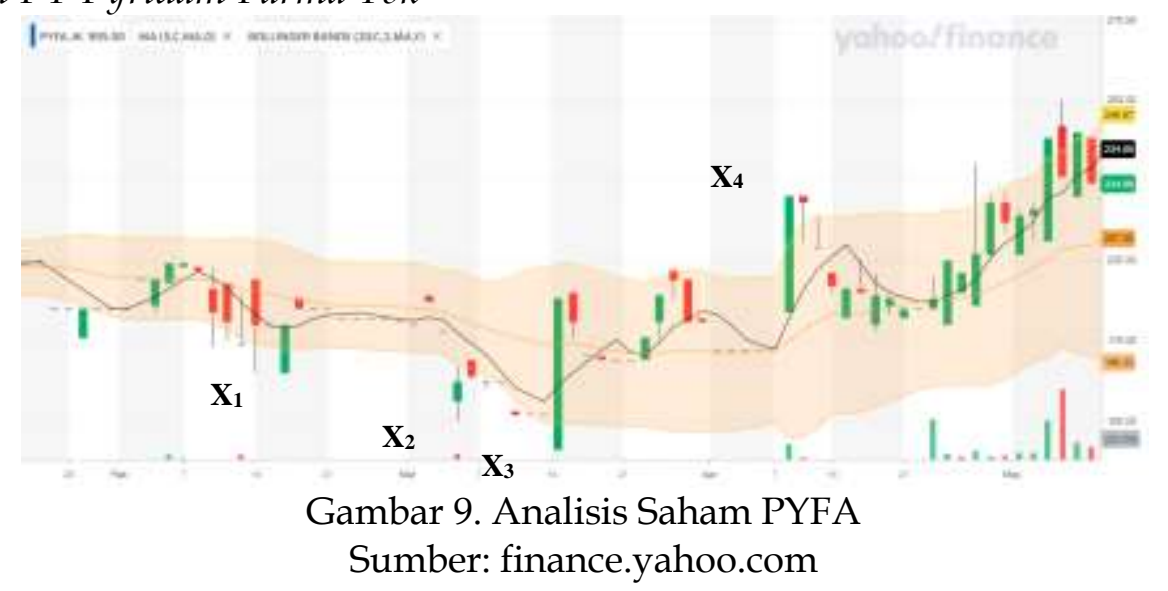

Pada gambar 9 terlihat bahwa pergerakan harga saham Pyridam Farma cenderung tidak stabil. Pada bulan Februari volatilitas emiten PYFA juga tergolong rendah. Titik X1 dan X2 menunjukkan keadaan oversold. Namun pada saat tersebut pasar cenderung sepi. Kondisi ini tidak mengindikasikan sinyal beli, trader sebaiknya holding/menahan sahamnya. Pada titik X4, harga telah menyentuh garis upper band yang menunjukkan bahwa pasar sedang dalam keadaan overbought. Pada kondisi ini sebaiknya trader mengambil keputusan jual sebelum harga terus merosot dengan penawaran tertinggi Rp220. Namun yang terjadi selanjutnya adalah harga bergerak dalam trend naik pada bulan April hingga Mei 2020.

\section{Analisis Saham PT Industri Jamu dan Farmasi Sidomuncul Tbk.}

Pada gambar 10 menunjukkan emiten saham SIDO cenderung terjadi uptrend di bulan Februari. Pada saat awal munculnya virus corona di Indonesia, Sidomuncul berada dalam trend sideway. Selanjutnya muncul titik X1 dimana harga menembus lower band. Pada titik X2 harga kembali menyentuh lower band diikuti dengan pita bollinger yang melebar dengan rentang harga Rp. 475-Rp. 505. Pada kondisi ini, trader sebaiknya mengambil keputusan beli karena harga diprediksi akan mengalami uptrend. Harga terus bergerak naik hingga muncul sinyal jual yang ditunjukkan oleh indikator bollinger. Pada titik X3 menunjukkan keadaan overbought dengan harga tertinggi menyentuh Rp. 710 dan sebaiknya trader menjual saham pada saat tersebut. 


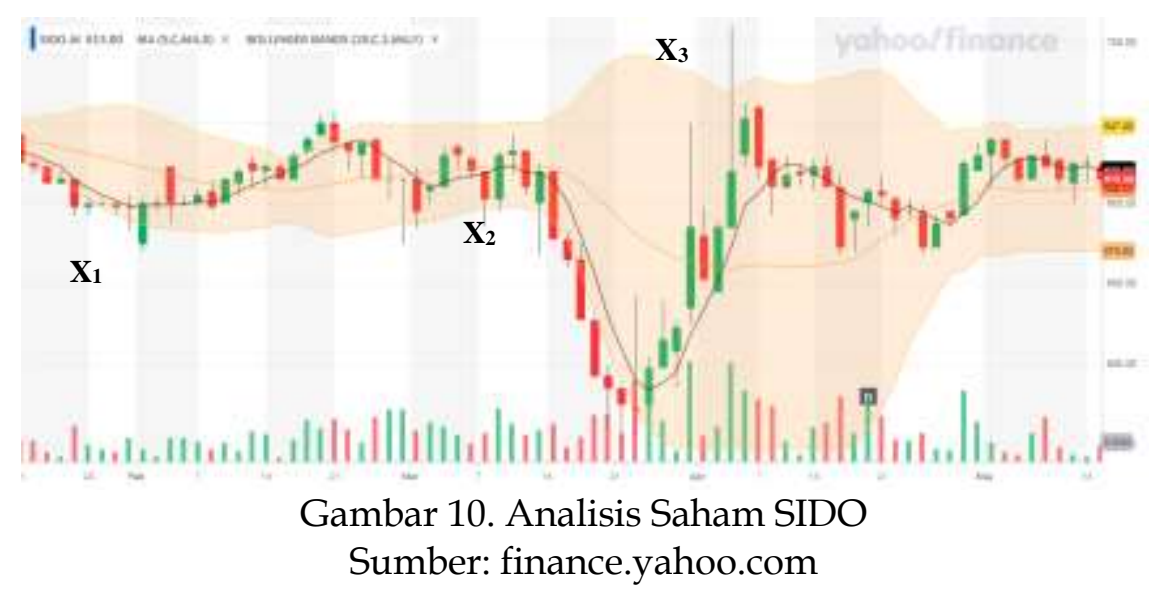

Analisis Saham PT Phapros Tbk

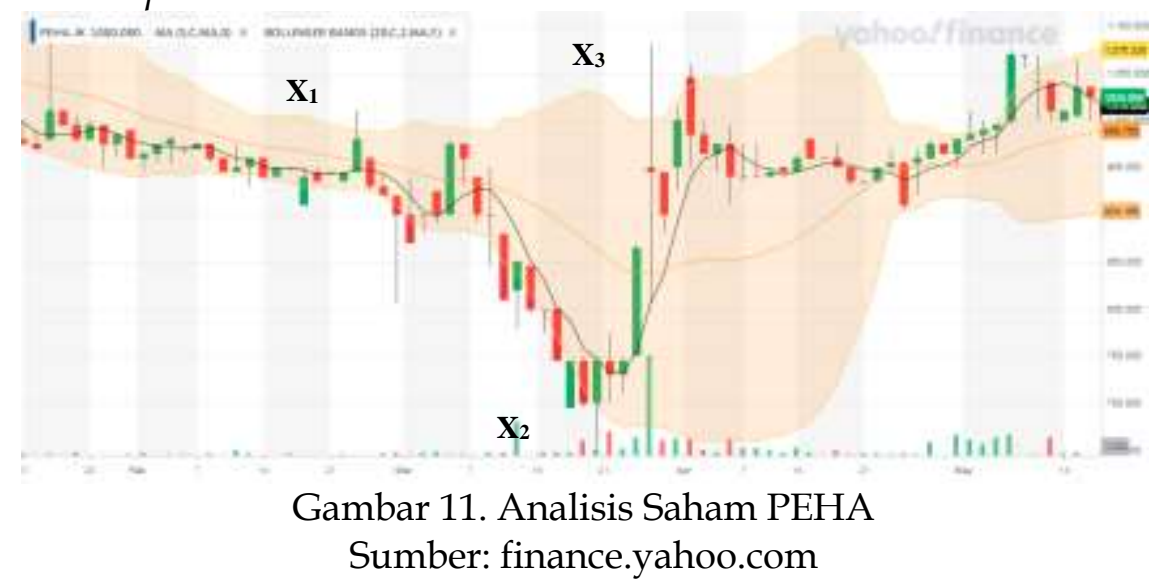

Dari gambar 11 terlihat pergerakan harga saham PEHA cenderung downtrend pada bulan Februari dan volatilitas tergolong rendah. Kemudian muncul sinyal jual pada saat harga menembus upper band (X1) dengan penawaran harga tertinggi Rp1010. Harga diprediksi akan bergerak turun sehingga trader disarankan untuk menjual sahamnya. Emiten PEHA terus mengalami penurunan hingga bulan Maret. Selanjutnya harga menembus lower band (X2) serta pita bollinger melebar dengan harga terendah Rp745. Hal ini mengindikasikan bahwa harga akan bergerak naik dan trader disarankan untuk mengambil keputusan beli. Kemudian sinyal jual kembali muncul pada titik X3 ditunjukkan dengan harga menembus upper band. Pada bulan April, harga saham cenderung bergerak dalam trend sideway.

\section{Analisis Saham PT Tempo Scan Pacific Tbk}

Dari gambar 12 diketahui bahwa pergerakan harga saham TSPC pada bulan Februari cenderung sideway. Pada saat harga saham menembus lower band (X1) dengan terendah yaitu Rp960 mengindikasikan sinyal beli, karena harga diprediksi akan bergerak naik. Selanjutnya sinyal jual ditunjukkan oleh indikator bollinger pada titik X2 dengan harga penawaran tertinggi Rp1230. Harga saham bergerak sideway pada akhir bulan April. 


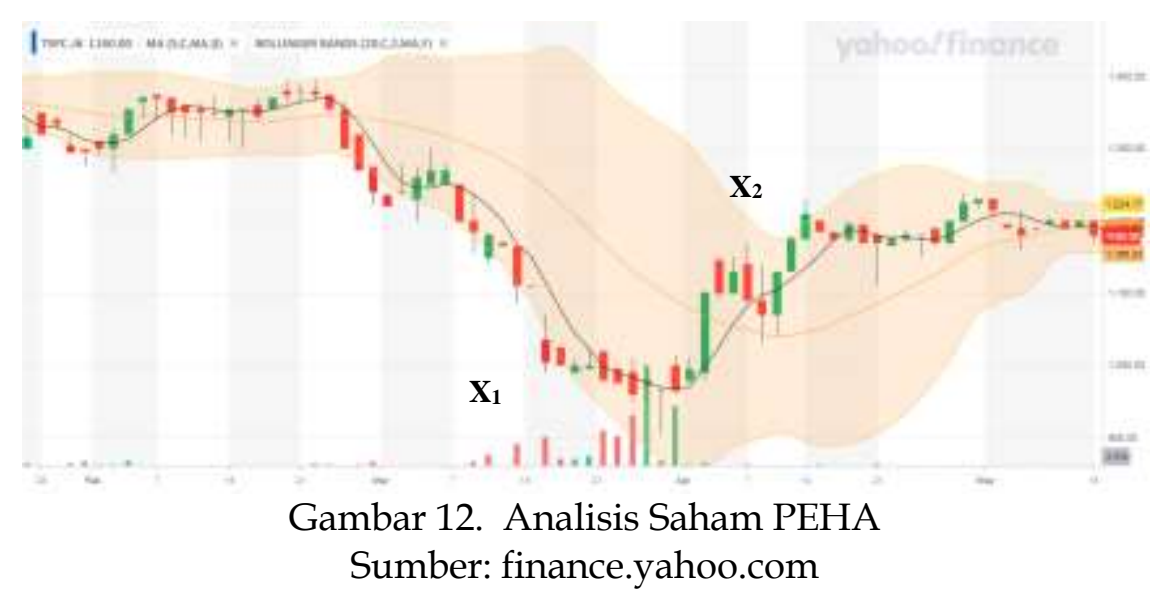

\section{TEKNIK ANALISIS DATA}

Analisis Statistik Deskriptif

Tabel 2. Hasil Statistik Deskriptif Bollinger Band

\begin{tabular}{|l|c|r|r|c|c|r|}
\hline & N & Minimum & Maximum & Sum & Mean & Std. Deviation \\
\hline Harga Realita & 558 & 152,00 & 2490,00 & 627526,57 & 1124,5996 & 610,91200 \\
Harga Bollinger & 558 & 170,00 & 2681,00 & 629925,38 & 1130,9253 & 622,90024 \\
Valid N (listwise) & 558 & & & & & \\
\hline
\end{tabular}

Sumber: Data Diolah (2020)

Tabel 2 menunjukan bahwa harga minimum pada indikator Bollinger Band yaitu 170, harga maksimum sebesar 2681, nilai mean 1130,9253 dengan standar deviasi sebesar 622,90024 yang artinya data yang didapatkan bagus karena nilai standar deviasi tidak lebih dari nilai mean. Pada harga realita diketahui harga minimum yaitu sebesar 152, harga maksimum sebesar 2490, mean sebesar 1124,5996 dengan nilai standar deviasi sebesar 610,91200 yang artinya data yang didapatkan bagus karena nilai standar deviasi tidak lebih besar dari mean dan memiliki penyimpangan yang kecil.

\section{Uji Normalitas}

Tabel 3. Hasil Uji Normalitas Bollinger Band One-Sample Kolmogorov-Smirnov Test

\begin{tabular}{|ll|r|r|}
\hline & & Harga Bollinger & Harga Realita \\
\hline N & & 558 & 558 \\
& Mean & 1130,9253 & 1124,5996 \\
Most Extreme Differences & Std. Deviation & 622,90024 & 610,91200 \\
& Absolute &, 008 &, 010 \\
& Positive &, 008 &, 010 \\
& Negative &,- 008 &,- 009 \\
Test Statistic & &, 008 &, 010 \\
Asymp. Sig. (2-tailed) & &, $200^{\mathrm{c}, \mathrm{d}}$ &, $200^{\mathrm{c}, \mathrm{d}}$ \\
\hline
\end{tabular}
a. Test distribution is Normal.
b. Calculated from data.
c. Lilliefors Significance Correction. 
d. This is a lower bound of the true significance.

Sumber: Data Diolah (2020)

Pada tabel 3 dapat dilihat bahwa uji normalitas menurut harga prediksi Bollinger Band dan realita sama-sama memiliki hasil 0,200 yang artinya data berdistribusi normal karena memiliki hasil lebih besar dari 0,05. Karena data terdistribusi normal selanjutnya dilakukan uji hipotesis menggunakan uji Paired Sample t-Test.

Uji Paired Sample T-Test

Tabel 4. Hasil Uji Beda Bollinger Band

Paired Samples Test

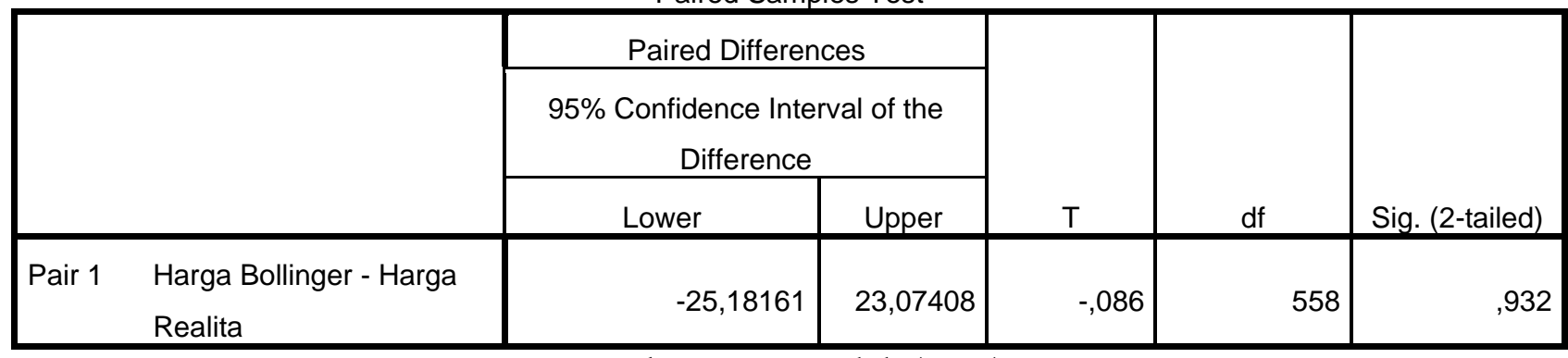

Sumber: Data Diolah (2020)

Dari tabel uji paired sample t-test dapat dilihat bahwa hasil uji beda menurut harga prediksi Bollinger Band dan harga realita menghasilkan asymp.sig sebesar 0,932 yang artinya $\mathrm{HO}$ diterima karena nilai probabilitias $>0,05$ yang artinya tidak terdapat perbedaan yang signifikan antara harga prediksi Bollinger Band dengan harga realita yang terjadi.

\section{Tingkat Akurasi}

Persentase keakuratan dengan menggunakan indikator Bollinger Band dapat dihitung dengan rumus:

(Total sinyal sukses) / (total keseluruhan sinyal) $x 100 \%$

Dari keseluruhan sinyal yang muncul dari indikator Bollinger Band pada sembilan perusahaan selama Feb1ruari hingga April 2020 terdapat 25 sinyal, diantaranya merupakan sinyal yang akurat sedangkan sisanya tidak akurat. Persentase keakuratan indikator Bollinger yaitu $22 / 25 \times 100 \%=88 \%$

\section{PEMBAHASAN}

Berdasarkan uji Paired Sample T-test, diperoleh nilai signifikansi yang menunjukkan bahwa indikator Bollinger Band tidak memiliki perbedaan yang signifikan dengan harga realita. Hal ini membuktikan indikator teknikal tersebut akurat dalam memprediksi harga pada saham sub sektor farmasi periode Februari hingga April 2020 meskipun di tengah kondisi pasar yang sangat berfluktuatif akibat pandemi.

Hasil penelitian ini mendukung penelitian Roy \& Hermuningsih (2016) yang menyatakan bahwa keputusan untuk membeli saham yang tepat adalah ketika harga saham berada pada garis atau di luar garis lower band. Dan keputusan untuk menjual yang tepat adalah ketika harga saham berada pada garis atau di luar garis upper band. Penelitian Baining \& Fadhillah (2017) juga menunjukkan bahwa indikator Bollinger Bands terbukti 
optimal dalam penggunaannya untuk melihat sinyal transaksi. Untuk hasil yang diberikan oleh indikator Bollinger Bands lebih tinggi dibandingkan dengan indikator Moving Average dan RSI.

Hasil penelitian ini sesuai dengan pendapat Ong (2016), pada sebuah uptrend yang kuat harga akan berfluktuasi terus di sekitar garis atas atau upper band. Pada sebuah downtrend yang kuat harga akan terus menempel pada garis bawah atau lower bands. Karena hal ini maka sinyal yang didapat dari indikator Bollinger Bands lebih baik dikonfirmasi lagi dengan teknik lain (Ong, 2016).

Perhitungan garis Bollinger menggunakan standar deviasi. Standar deviasi adalah sebuah rumus matematika yang mengukur volatilitas, menunjukkan bagaimana harga dapat berfluktuasi di sekitar nilai sebenarnya. Standar deviasi mengukur volatilitas harga dengan menghubungkan sebuah rentang harga pada pergerakan rata-ratanya. Semakin tinggi nilai standar deviasi, semakin lebar jarak antara harga dengan pergerakan rataratanya, semakin volatil suatu instrumen maka semakin tersebar candle harganya. Semakin rendah nilai standar deviasi, semakin rapat jarak antara harga dengan pergerakan rataratanya, semakin tidak volatil suatu instrumen maka semakin rapat candle harganya. Seperti grafik pergerakan harga pada pembahasan sebelumnya, dapat terlihat indikator Bollinger Band cukup agresif dalam memberikan sinyal transaksi.

\section{KESIMPULAN}

Penelitian ini bertujuan untuk mengetahui kinerja penggunaan indikator teknikal dalam pengambilan keputusan bertransaksi saham, yang terlihat dari seberapa optimal kinerja indikator Bollinger Band dalam memprediksi harga saham. Dari hasil pengujian dapat dilihat bahwa indikator Bollinger Bands terbukti optimal dalam penggunaannya untuk melihat sinyal transaksi.

Perlu dilakukan pengembangan lebih lanjut dengan melakukan pengujian menggunakan indikator-indikator teknikal selain indikator yang digunakan pada penelitian ini. Selain itu, penelitian berikutnya diharapkan dapat melakukan pengujian pada saham-saham indeks yang berbeda dengan periode amatan yang pendek atau tetap menggunakan saham-saham sub sektor farmasi namun dengan periode amatan yang lebih panjang. Hal ini penting dilakukan untuk dapat membuktikan lebih jauh apakah dalam konteks bursa efek Indonesia keakuratan dan keunggulan metode bollinger band dapat digeneralisasi pada konteks berbagai indeks saham berbeda dan berbagai jangka waktu amatan yang berbeda.

Secara praktis, bagi investor, dalam menggunakan analisis teknikal untuk pengambilan suatu keputusan investasi, sebaiknya tidak menggunakan satu indikator saja, melainkan juga menggunakan indikator lain agar dapat diperbandingkan sehingga bisa diperoleh hasil keputusan investasi yang tepat.

\section{DAFTAR PUSTAKA}

Baining, M. E., \& Fadhillah, M. S. (2017). “Analisis teknik penggunaan moving average, relative strength index dan bollinger bands dalam menghasilkan return saham pada perusahaan yang terdaftar di Jakarta Islamic Index (JII). Jurnal Syari'ah, 5(2).

BBC. (2020). Krisis ekonomi akibat Covid-19: IMF perkirakan 'luka ekonomi' karena krisis global akibat 
pandemi virus corona lebih buruk dari perkiraan. Bbc.com. Diakses dari https://www.bbc.com/indonesia/dunia-53168814.

BPS. (2020). Ekonomi Indonesia triwulan II 2020 turun 5,32 persen. Diakses dari https:// www.bps.go.id/pressrelease/2020/08/05/1737/-ekonomi-indonesia-triwulan-ii-2020turun-5-32-persen.html.

Finance.com. (2020). Chart emiten. Finance.yahoo.com. Diakses dari https:// finance.yahoo.com/quote/category=fin-srch.

Kompas. (2020). Ini 10 negara jatuh resesi akibat pandemi, bagaimana dengan Indonesia? Kompas.com. Diakses dari https://amp-kompas com.cdn.ampproject.org/v/s/amp.kompas.com/money/read/2020/08/13/133706626/ini-10negara-jatuh-resesi-akibat-pandemi-bagaimana-dengan-indonesia?

Otoritas Jasa Keuangan. (2020). Perkembangan indeks sektoral 2020. ojk.go.id. Diakses dari https://www.google.com/search?q=PERKEMBANGAN+INDEKS+SEKTORAL+2020+OJK\&oq=PE RKEMBANGAN+INDEKS+SEKTORAL+2020+OJK\&aqs=chrome..69i57.10322j0j9\&sourceid=chrome \&ie=UTF-8.

Ong, E. (2016). Technical analysis for mega profit. Jakarta: PT Gramedia Pustaka Utama.

Roy, G. W., \& Hermuningsih, S. (2016). “Analisis teknikal saham menggunakan indikator bollinger bands dan relative strength index untuk pengambilan keputusan investasi. Jurnal Manajemen, 6(1).

Sugiyono. (2017). Metode penelitian bisnis. Bandung: Alfabeta.

Sunariyah. (2013). Pengantar pengetahuan pasar modal. Edisi 6. Yogyakarta: UPP STIM YKPN. 